\title{
Effects of Additives on the Surface Roughness and Throwing Power of Copper Deposited from Electrorefining Solutions ${ }^{*}$
}

\author{
Atsuhiro Suzuki ${ }^{1}$, Satoshi Oue ${ }^{2}$, Shigeo Kobayashi ${ }^{3}$ and Hiroaki Nakano ${ }^{2}$ \\ ${ }^{1}$ Department of Materials Process Engineering, Kyushu University, Fukuoka 819-0395, Japan \\ ${ }^{2}$ Department of Materials Science \& Engineering, Kyushu University, Fukuoka 819-0395, Japan \\ ${ }^{3}$ Department of Applied Chemistry and Biochemistry, Kyushu Sangyo University, Fukuoka 813-8503, Japan
}

\begin{abstract}
To elucidate the synergistic effects of gelatin, thiourea, and chloride ions on the surface roughness, throwing power, and polarization curves for $\mathrm{Cu}$ deposition from electrorefining solutions, $\mathrm{Cu}$ electrodeposition was performed at a current density of $200 \mathrm{~A} \cdot \mathrm{m}^{-2}$ and a charge of $5 \times 10^{5} \mathrm{C} \cdot \mathrm{m}^{-2}$ in an unagitated sulfate solution containing $0.708 \mathrm{~mol} \cdot \mathrm{dm}^{-3}$ of $\mathrm{CuSO}_{4}$ and $2.04 \mathrm{~mol}^{-\mathrm{dm}^{-3}}$ of $\mathrm{H}_{2} \mathrm{SO}_{4}$ at a temperature of $60^{\circ} \mathrm{C}$. In solutions containing all three additives (gelatin, thiourea, and chloride ions), the surface roughness of deposited Cu decreased with increasing thiourea and gelatin concentrations and decreasing chloride ions concentration. On the other hand, the throwing power of deposited $\mathrm{Cu}$ improved with decreasing thiourea concentration and increasing gelatin concentration in solutions containing all three additives. The throwing power of deposited $\mathrm{Cu}$ was significantly improved in solutions containing both gelatin and chloride ions. The polarization resistance $\mathrm{d} E / \mathrm{d} i$ for $\mathrm{Cu}$ deposition increased in solutions containing both gelatin and chloride ions, resulting in an improvement in the throwing power of Cu deposition. As small amounts of thiourea have a depolarization effect on $\mathrm{Cu}$ deposition, a smoothing effect is expected to result from the promotion of deposition at recesses. [doi:10.2320/matertrans.M2017215]
\end{abstract}

(Received July 7, 2017; Accepted September 1, 2017; Published September 29, 2017)

Keywords: copper, electrorefining, electrolysis, gelatin, thiourea, chloride ions, throwing power, surface roughness, polarization curve, depolarization

\section{Introduction}

In the electrorefining of $\mathrm{Cu}$, gelatin ${ }^{1-3)}$ and thiourea are added into the electrolyte to smooth the surfaces of deposits and suppress the codeposition of impurities. Chloride ions are also added to facilitate the formation of slime resulting from the anode. When gelatin, thiourea, and chloride ions are all added to the electrolyte, the cathode potential shifts toward the less noble direction, causing the crystal grains of the deposited $\mathrm{Cu}$ to become finer. ${ }^{4-8)}$ The effects of straightchain polymer additives ${ }^{9,10)}$ (e.g., gelatin and polyethylene glycol), thiourea ${ }^{11,12)}$ and chloride ions ${ }^{13-15)}$ along with the synergistic effects ${ }^{16)}$ of polymer additives and chloride ions on $\mathrm{Cu}$ electrorefining were reported. However, there are many ambiguities regarding the synergistic effects of gelatin, thiourea, and chloride ions on the surface roughness and throwing power of deposited $\mathrm{Cu}^{17-20)}$ Therefore, in this study, the synergistic effects of these additives on the surface morphology, surface roughness, and throwing power of $\mathrm{Cu}$ deposited in the initial stage ( $\mathrm{Cu}$ thickness of up to approximately $18 \mu \mathrm{m}$ ) were investigated. The throwing power was quantitatively evaluated by measuring the thickness profile of deposited $\mathrm{Cu}$. To consider the effects of the additives on the surface roughness and throwing power of the deposited $\mathrm{Cu}$, the effects of gelatin, thiourea, and chloride ions on the polarization curve for $\mathrm{Cu}$ deposition were examined.

\section{Experimental}

Table 1 shows the solution and electrolysis conditions used to investigate the effects of additives on $\mathrm{Cu}$ electrodeposition. An electrolytic solution was prepared by dissolving

*This Paper was Originally Published in Japanese in J. Japan Inst. Met. Mater. 81 (2017) 358-365.
Table 1 Electrolysis conditions.

\begin{tabular}{ll}
\hline Bath & $\mathrm{CuSO}_{5} \cdot 5 \mathrm{H}_{2} \mathrm{O}\left(\mathrm{mol} \cdot \mathrm{dm}^{-3}\right) 0.708$ \\
composition & $\mathrm{H}_{2} \mathrm{SO}_{4}\left(\mathrm{~mol} \cdot \mathrm{dm}^{-3}\right) 2.04$ \\
& Gelatin $\left(\mathrm{mg} \cdot \mathrm{dm}^{-3}\right)$ \\
& $0.171(\times 1 / 10), 1.71(\times 1), 17.1(\times 10)$ \\
& Thiourea $\left(\mathrm{mmol} \cdot \mathrm{dm}^{-3}\right)$ \\
& $0.0023(\times 1 / 10), 0.023(\times 1), 0.23(\times 10), 2.3(\times 100)$ \\
& $\mathrm{Cl}^{-}\left(\mathrm{mmol} \cdot \mathrm{dm}^{-3}\right) 0.165(\times 1 / 10), 1.65(\times 1), 16.5(\times 10)$ \\
\hline Operating & Anode current density $\left(\mathrm{A} \cdot \mathrm{m}^{-2}\right) 200$ \\
conditions & Temperature $\left({ }^{\circ} \mathrm{C}\right) 60$ \\
& Cathode Cu $(3 \mathrm{~cm} \times 3 \mathrm{~cm})$ \\
& Anode Cu $(6 \mathrm{~cm} \times 7 \mathrm{~cm})$ \\
& Amount of charge No stirring $\left(\mathrm{C} \cdot \mathrm{m}^{-2}\right) 5 \times 10^{5}$ \\
\hline
\end{tabular}

$\times 1$ : standard concentration, $\times 1 / 10$ : one tenth of standard, $\times 10$ : ten times of standard

reagent-grade $\mathrm{CuSO}_{4} \quad\left(0.708 \mathrm{~mol} \cdot \mathrm{dm}^{-3}\right)$ and $\mathrm{H}_{2} \mathrm{SO}_{4}$ $\left(2.04 \mathrm{~mol} \cdot \mathrm{dm}^{-3}\right)$ in distilled and ion-exchanged water. Gelatin $\left(0.171,1.71\right.$, and $17.1 \mathrm{mg} \cdot \mathrm{dm}^{-3}$; standard concentration $=1.71 \mathrm{mg} \cdot \mathrm{dm}^{-3} ;$ Nippi Peptide, PA-10) with a mean molecular weight of 20000, thiourea $(0.0225$ to $2.3 \mathrm{mmol} \cdot \mathrm{dm}^{-3} ; \quad$ standard concentration = $\left.0.0023 \mathrm{mmol} \cdot \mathrm{dm}^{-3}\right)$, and chloride ions $(0.165,1.65$, $16.5 \mathrm{mmol} \cdot \mathrm{dm}^{-3}$; standard concentration $=1.65 \mathrm{mmol} \cdot \mathrm{dm}^{-3}$ ) in the form of $\mathrm{HCl}$ were added to the electrolyte. The standard concentrations of gelatin, thiourea, and chloride ions were set based on the concentrations in a principal electrolytic of a Japanese copper refinery. $\mathrm{Cu}$ sheets of $3 \mathrm{~cm} \times 3 \mathrm{~cm}$ and $6 \mathrm{~cm} \times 7 \mathrm{~cm}$ with sealed rear side were used as the cathode and anode, respectively. Electrodeposition was performed in $0.5 \mathrm{~L}$ of unagitated solution under coulostatic $\left(500 \mathrm{kC} \cdot \mathrm{m}^{-2}\right)$ and galvanostatic conditions $\left(200 \mathrm{~A} \cdot \mathrm{m}^{-2}\right)$ at $60^{\circ} \mathrm{C}$. For general deposition, the electrolyte is agitated to make the solution composition and current density distribution uniform and to decrease the thickness of the diffusion 
layer of $\mathrm{Cu}^{2+}$ ions. However, in this study, the deposition was performed in unagitated solutions so the electrolyte is only circulated in the electrolysis tank during the actual electrorefining, and as a result, is almost quiescent except for convection at the cathode surface. Since gelatin was assumed to gradually decompose in the electrolyte, electrodeposition was immediately conducted after its addition into the electrolyte. The polarization curve was obtained by measuring the corresponding cathode potential while changing the current density every $3 \mathrm{~min}$ in the range of 1 to $2,000 \mathrm{~A} \cdot \mathrm{m}^{-2}$. The cathode potentials were measured using a saturated $\mathrm{KCl}$ and $\mathrm{Ag} / \mathrm{AgCl}$ reference electrode $(0.199 \mathrm{~V}$ vs. a normal hydrogen electrode, $25^{\circ} \mathrm{C}$ ). The potentials were plotted with reference to the normal hydrogen electrode.

The center area of the surface of deposited $\mathrm{Cu}$ was observed by scanning electron microscopy (SEM), and the elemental distribution was examined by electron probe microanalysis (EPMA). The surface roughness of deposited $\mathrm{Cu}$ was evaluated by centerline average roughness $R_{a}$ [Japanese Industrial Standard (JIS) B 0601] using a SURFCOM 1500DX-3DF instrument (Tokyo Seimitsu Co.). The surface roughness was evaluated at a cutoff wavelength of $0.8 \mathrm{~mm}$, measurement length of $10 \mathrm{~mm}$, and measurement rate of $0.15 \mathrm{~mm} \cdot \mathrm{s}^{-1}$ based on JIS. The throwing power of deposited $\mathrm{Cu}$ was evaluated by the thickness profile of $\mathrm{Cu}$. The height of deposited $\mathrm{Cu}$ was measured at a cutoff wavelength of $0.08 \mathrm{~mm}$, measurement length of $30 \mathrm{~mm}$ (sample edge to sample edge), and measurement rate of $3 \mathrm{~mm} \cdot \mathrm{s}^{-1}$ using a SURFCOM 1500DX-3DF instrument. The thickness of deposited $\mathrm{Cu}$ was calculated as the difference in height before and after deposition. The $x$-axis and $z$-axis in thickness profile of deposited $\mathrm{Cu}$ show the measurement direction and thickness direction of $\mathrm{Cu}$, respectively. The region where the slope $(\mathrm{d} z / \mathrm{d} x)$ of the thickness profile of deposited $\mathrm{Cu}$ is less than $0.3 \mu \mathrm{m} \cdot \mathrm{mm}^{-1}$ was defined as flat areas, and the throwing power of deposited $\mathrm{Cu}$ was evaluated from the lengths of the flat areas.

\section{Results and Discussion}

\subsection{Effects of additives on the surface morphology of deposited $\mathrm{Cu}$}

Figure 1 shows the SEM images of the surfaces of $\mathrm{Cu}$ deposited from the solutions containing single additive (gelatin, thiourea, and chloride ions). $\mathrm{Cu}$ deposited from the additive-free solution $(\mathrm{k})$ comprised aggregated crystals with sizes of approximately $10 \mu \mathrm{m}$. The grain size of $\mathrm{Cu}$ deposited from the solution containing $0.171 \mathrm{mg} \cdot \mathrm{dm}^{-3}$ gelatin (a) was smaller than that of $\mathrm{Cu}$ deposited from the additive-free solution. In contrast, the size became larger when $1.71 \mathrm{mg} \cdot \mathrm{dm}^{-3}$ gelatin was added to the solution (b). Further increasing the gelatin concentration to $17.1 \mathrm{mg} \cdot \mathrm{dm}^{-3}$ (c) caused the $\mathrm{Cu}$ grain size to decrease. With the addition of thiourea, the grain size of deposited $\mathrm{Cu}$ decreased with increasing thiourea concentration [(d), (e), (f), and (g)]. On the other hand, with the addition of 0.165 or $1.65 \mathrm{mmol} \cdot \mathrm{dm}^{-3}$ chloride ions [(h) and (i)], the concave and convex aggregated crystals of deposited $\mathrm{Cu}$ became more clear compared to those deposited from the additive-free solution. With the addition of $1.65 \mathrm{mmol} \cdot \mathrm{dm}^{-3}$ of chloride ions (i), which is the standard concentration, the surfaces of the aggregated crystals were not smooth and comprised layers of plate-like crystals. Increasing the chloride ion concentration to $16.5 \mathrm{mmol} \cdot \mathrm{dm}^{-3}(\mathrm{j})$, which is ten times the standard concentration, caused the morphology of deposited $\mathrm{Cu}$ to change significantly; the resulting deposits contained both fine grains and large plate-like crystals. The components of these fine grains and large crystals were examined by EPMA.

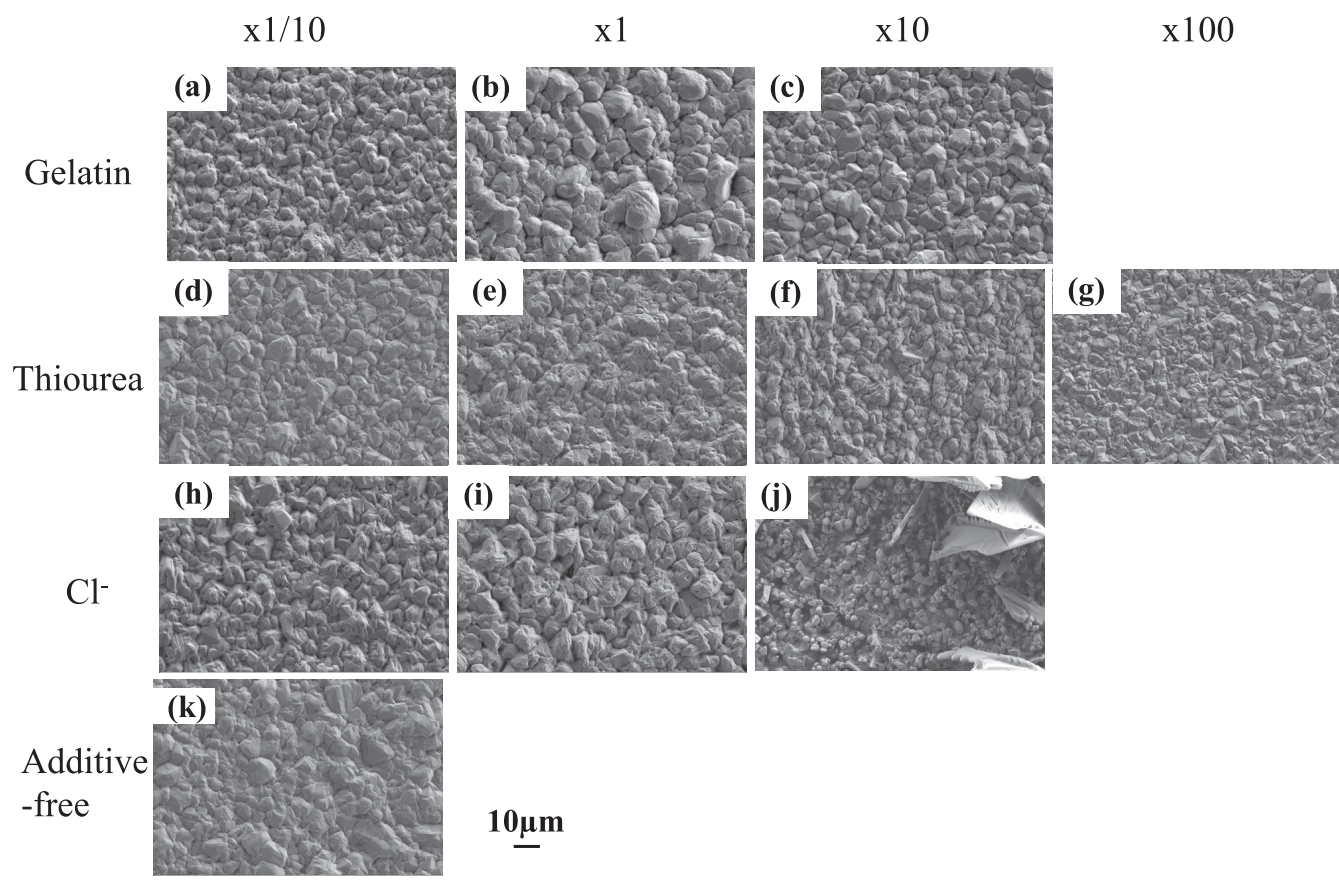

Fig. 1 Surface SEM images of Cu electrodeposited from solutions containing various concentrations of single additives: gelatin at (a) 0.171, (b) 1.71, and (c) $17.1 \mathrm{mg} \cdot \mathrm{dm}^{-3}$; thiourea at (d) 0.0023 , (e) 0.023 , (f) 0.23 , and (g) $2.3 \mathrm{mmol} \cdot \mathrm{dm}^{-3}$; $\mathrm{Cl}^{-}$at (h) 0.165 , (i) 1.65 , and (j) $16.5 \mathrm{mmol} \cdot \mathrm{dm}{ }^{-3}$; and (k) without any additives as a reference. 
Figure 2 shows the EPMA image of the surface of $\mathrm{Cu}$ deposited from the solution containing $16.5 \mathrm{mmol} \cdot \mathrm{dm}^{-3}$ chloride ions. The analysis of the fine-grained crystals (b) within the square in (a) indicated components of $\mathrm{CuCl}$ besides $\mathrm{Cu}$. $\mathrm{Cu}$ deposition from solution containing chloride ions was reported to proceed via $\mathrm{CuCl},{ }^{16)}$ and $\mathrm{CuCl}$ deposits comprised squamous and fine-grained crystals. ${ }^{16)}$ In this study, with the addition of $16.5 \mathrm{mmol} \cdot \mathrm{dm}^{-3}$ chloride ions (ten times larger than the standard concentration), the detection of $\mathrm{CuCl}$ in deposits is due to that the large amounts of intermediate $\mathrm{CuCl}$ was formed and involved into deposits in the form of non-reduced state. Therefore, in the following experiment, the concentration of chloride ion in solutions was fixed at 0.165 or $1.65 \mathrm{mmol} \cdot \mathrm{dm}^{-3}$.

Figure 3 shows the SEM images of the surfaces of $\mathrm{Cu}$ deposited from solutions containing various amounts of the three additives (gelatin, thiourea, and chloride ions). The standard concentrations of gelatin, thiourea, and chloride ions were $\quad 1.71 \mathrm{mg} \cdot \mathrm{dm}^{-3}, \quad 0.023 \mathrm{mmol} \cdot \mathrm{dm}^{-3}, \quad$ and $1.65 \mathrm{mmol} \cdot \mathrm{dm}^{-3}$, respectively. With increasing gelatin concentration, the crystal size of deposited $\mathrm{Cu}$ decreased [(b), (c), and (d)]. As shown in Fig. 1, with the addition of gelatin only, the grain size of deposited $\mathrm{Cu}$ was larger with the addition of $1.71 \mathrm{mg} \cdot \mathrm{dm}^{-3}$ gelatin than with $0.171 \mathrm{mg} \cdot \mathrm{dm}^{-3}$, dif- ferent from the trend observed for solutions containing all three additives. With the addition of thiourea and gelatin, the grain size of deposited $\mathrm{Cu}$ decreased with increasing thiourea concentration $[(\mathrm{e}),(\mathrm{c}),(\mathrm{f})$, and $(\mathrm{g})]$, identical to the trend observed for the addition of thiourea only. On the other hand, with addition of chloride ions, the grain size of $\mathrm{Cu}$ deposited from the solution containing $0.165 \mathrm{mmol} \cdot \mathrm{dm}^{-3}$ chloride ions $(\mathrm{h})$ was smaller than that of $\mathrm{Cu}$ deposited from the solution containing $1.65 \mathrm{mmol} \cdot \mathrm{dm}^{-3}$ of chloride ions (c), and the surfaces of the deposits were smoother.

\subsection{Effects of additives on the surface roughness and throwing power of deposited $\mathrm{Cu}$}

Figure 4 shows the surface roughnesses of $\mathrm{Cu}$ deposited from the solutions containing single additives (gelatin, thiourea, or chloride ions). With the addition of thiourea at concentrations of 0.0023 and $0.023 \mathrm{mmol} \cdot \mathrm{dm}^{-3}$, the surface roughness was almost identical to that of $\mathrm{Cu}$ deposited in thiourea-free solution. Upon increasing the thiourea concentration to 0.23 and $2.3 \mathrm{mmol} \cdot \mathrm{dm}^{-3}$, the surface roughness of $\mathrm{Cu}$ significantly decreased. For the addition of chloride ions, the concentration of $0.165 \mathrm{mmol} \cdot \mathrm{dm}^{-3}$ resulted in a larger surface roughness compared to the chloride ion-free solution. Increasing the concentration to $1.65 \mathrm{mmol} \cdot \mathrm{dm}^{-3}$ caused
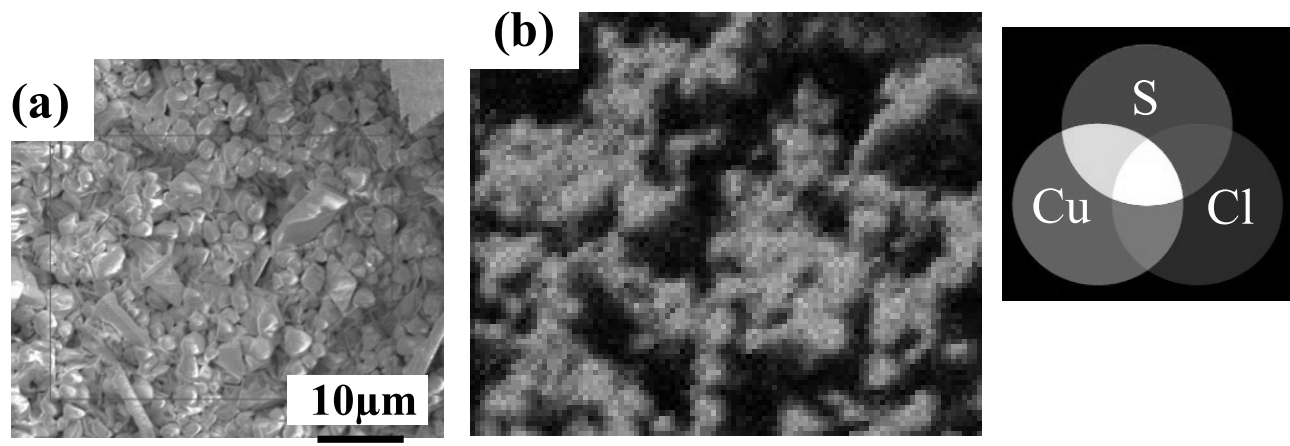

Fig. 2 (a) EPMA image of the surface of $\mathrm{Cu}$ deposited from the solution containing $16.5 \mathrm{mmol} \cdot \mathrm{dm}^{-3}$ of $\mathrm{Cl}^{-}$ions and (b) the elemental mapping of (a).
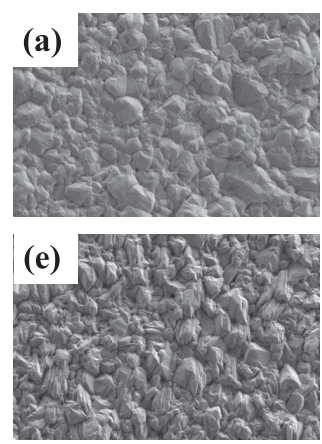
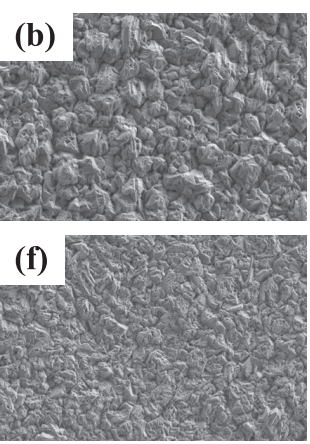
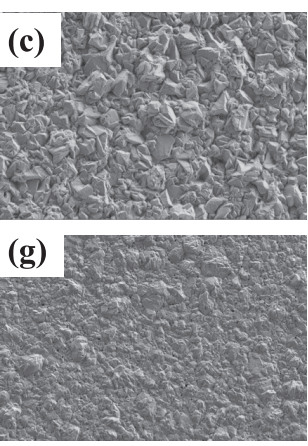
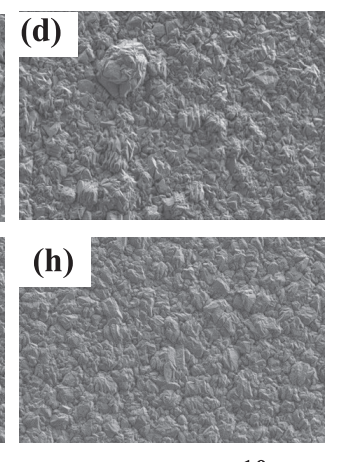

$10 \mu \mathrm{m}$

\begin{tabular}{|c|c|c|c|c|c|c|c|c|}
\hline & (a) & (b) & (c) & (d) & (e) & (f) & (g) & (h) \\
\hline Gelatin $\left(\mathrm{mg}-\mathrm{dm}^{-3}\right)$ & 0 & $0.171(\times 1 / 10)$ & $1.71(\times 1)$ & $17.1(\times 10)$ & & $1.71(\mathrm{x} 1)$ & & \\
\hline Thiourea $\left(\mathrm{mmol}^{-} \mathrm{dm}^{-3}\right)$ & 0 & 0.02 & $23(\times 1)$ & & $0.0023(\times 1 / 10)$ & $0.23(\times 10)$ & $2.3(\times 100)$ & $0.023(\times 1)$ \\
\hline $\mathrm{Cl}^{-}\left(\mathrm{mmol}^{-} \mathrm{dm}^{-3}\right)$ & 0 & & & 1.65 & $5(\times 1)$ & & & $0.165(\times 1 / 10)$ \\
\hline
\end{tabular}

Fig. 3 Surface SEM images of Cu deposited from solutions containing all three additives. 


\begin{tabular}{|c|c|c|c|c|c|}
\hline $\begin{array}{l}\text { Gelatin } \\
(\mathrm{mg} / \mathrm{L})\end{array}$ & $\begin{array}{c}\text { Thiourea } \\
(\mathrm{mM})\end{array}$ & $\begin{array}{c}\mathrm{Cl}^{\mathrm{Cl}} \\
(\mathrm{mM})\end{array}$ & & & \\
\hline 0 & 0 & $\mathbf{0}$ & 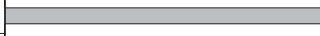 & & \\
\hline 0 & 0.0023 & 0 & & & \\
\hline 0 & 0.023 & 0 & & & \\
\hline 0 & 0.23 & $\mathbf{0}$ & $\square$ & & \\
\hline $\mathbf{0}$ & 2.3 & $\mathbf{0}$ & $\square$ & & \\
\hline $\mathbf{0}$ & $\mathbf{0}$ & 0.165 & & $\square$ & \\
\hline 0 & 0 & 1.65 & & & \\
\hline 0.171 & $\mathbf{0}$ & $\mathbf{0}$ & & & \\
\hline 1.71 & $\mathbf{0}$ & $\mathbf{0}$ & & $\square$ & \\
\hline 17.1 & $\mathbf{0}$ & $\mathbf{0}$ & $\prod_{1}$ & & \\
\hline
\end{tabular}

Fig. 4 Surface roughnesses of $\mathrm{Cu}$ deposited from solutions containing single additives.

the surface roughness of $\mathrm{Cu}$ to increase further. On the other hand, the surface roughness of $\mathrm{Cu}$ deposited from the solution containing $0.171 \mathrm{mg} \cdot \mathrm{dm}^{-3}$ gelatin $(1 / 10$ of standard $)$ was almost identical to that of $\mathrm{Cu}$ deposited from the gelatin-free solution. Upon increasing the gelatin concentration to $1.71 \mathrm{mg} \cdot \mathrm{dm}^{-3}$, the surface roughness increased. Further increasing the concentration to $17.1 \mathrm{mg} \cdot \mathrm{dm}^{-3}$ resulted in a decrease in surface roughness. The surface roughness of $\mathrm{Cu}$ deposited from the solution containing single additive of gelatin almost corresponded to the surface morphologies shown in Fig. 1.

Figure 5 shows the surface roughnesses of $\mathrm{Cu}$ deposited from solutions containing the three types of additives. The surface roughness of $\mathrm{Cu}$ deposited from the solution containing the standard concentrations of the three additives was smaller than that of $\mathrm{Cu}$ deposited from the additive-free solution. However, when the thiourea concentration was decreased to $0.0023 \mathrm{mmol} \cdot \mathrm{dm}^{-3}$, the surface roughness of $\mathrm{Cu}$ became larger than that of $\mathrm{Cu}$ deposited from the additive-free solution. This indicates that the addition of a low concentration of thiourea cannot counteract the increase in roughness generated by chloride ions. Increasing the thiourea concentration to 0.23 and $2.3 \mathrm{mmol} \cdot \mathrm{dm}^{-3}$ caused the surface roughness of $\mathrm{Cu}$ to decrease significantly. Decreasing the concentration of chloride ions to $0.165 \mathrm{mmol} \cdot \mathrm{dm}^{-3}$ ( $1 / 10$ of the standard concentration) also caused the surface roughness of $\mathrm{Cu}$ to decrease greatly. This corresponds to the surface morphology shown in Fig. 3. On the other hand, decreasing the gelatin concentration to $0.171 \mathrm{mg} \cdot \mathrm{dm}^{-3}$ increased the surface roughness, whereas increasing the gelatin concentration to $17.1 \mathrm{mg} \cdot \mathrm{dm}^{-3}$ decreased the roughness. That is, in the presence of all three additives, the surface roughness of $\mathrm{Cu}$ decreased with increasing gelatin concentration.

The synergistic effect of the additives on the throwing power of deposited $\mathrm{Cu}$ was evaluated from the $\mathrm{Cu}$ thickness profile. Figure 6 shows the thickness profiles of $\mathrm{Cu}$ deposited from solutions without additives and with the three additives at their standard concentrations. The $\mathrm{Cu}$ deposited from the additive-free solution (a) was thick at the edges and thin at the center. The $\mathrm{Cu}$ deposited from the solution containing all three additives (b) was somewhat thick at the

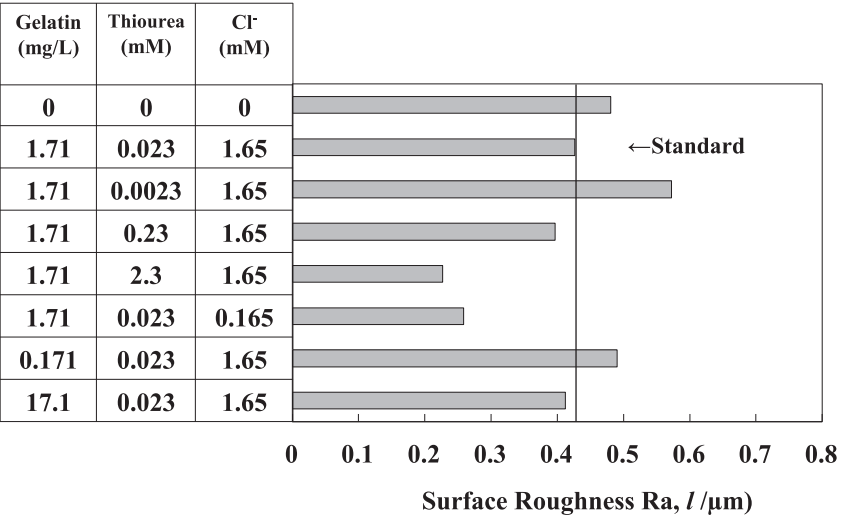

Fig. 5 Surface roughnesses of $\mathrm{Cu}$ deposited from solutions containing all three additives.

edges but more uniform than the $\mathrm{Cu}$ deposited from the additive-free solution. In this study, the region where the slope $(\mathrm{d} z / \mathrm{d} x)$ of the thickness profile of deposited $\mathrm{Cu}$ is less than $0.3 \mu \mathrm{m} \cdot \mathrm{mm}^{-1}$ was defined as flat areas, and the throwing power of deposited $\mathrm{Cu}$ was evaluated from the lengths of the flat areas. The $x$-axis and $z$-axis in thickness profile of deposited $\mathrm{Cu}$ show the measurement direction and thickness direction of $\mathrm{Cu}$, respectively.

Figure 7 shows the throwing powers of $\mathrm{Cu}$ deposited from solutions containing single additives. With the addition of chloride ions, the throwing power of $\mathrm{Cu}$ improved with increasing chloride ion concentration even though the chloride ions increased the surface roughness of $\mathrm{Cu}$ (Figs. 4 and 5). The throwing power also improved with increasing gelatin concentration, and the improvement obtained with $17.1 \mathrm{mg} \cdot \mathrm{dm}^{-3}$ of gelatin (10 times the standard concentration) was similar to that obtained with the addition of $1.65 \mathrm{mmol} \cdot \mathrm{dm}^{-3}$ chloride ions (standard). With the addition of thiourea only, the throwing power of deposited $\mathrm{Cu}$ was somewhat improved compared to that of $\mathrm{Cu}$ deposited from the additive-free solution.

Figure 8 shows the throwing powers of $\mathrm{Cu}$ deposited from solutions containing two additives at standard concentration. The throwing power was improved for all the combinations of additives, and the best improvement was achieved by the addition of gelatin and chloride ions. The improvement was identical to that obtained with the addition of all three additives.

Figure 9 shows the throwing powers of $\mathrm{Cu}$ deposited from solutions containing the three additives in various concentrations. The addition of the three additives at the standard concentrations significantly improved the throwing power compared to the additive-free solution. Decreasing the thiourea concentration to $0.0023 \mathrm{mmol} \cdot \mathrm{dm}^{-3}$ further improved the throwing power of $\mathrm{Cu}$. However, increasing the thiourea concentration to 0.23 and $2.3 \mathrm{mmol} \cdot \mathrm{dm}^{-3}$ resulted in a worse throwing power compared to the standard thiourea concentration $\left(0.023 \mathrm{mmol} \cdot \mathrm{dm}^{-3}\right)$. Although the throwing power of $\mathrm{Cu}$ was improved at any concentration of thiourea when only thiourea was added, in the presence of all three additives, the throwing power depended significantly on thiourea concentration. Decreasing the chloride ion concentration from the standard concentration to $0.165 \mathrm{mmol} \cdot \mathrm{dm}^{-3}$ caused 


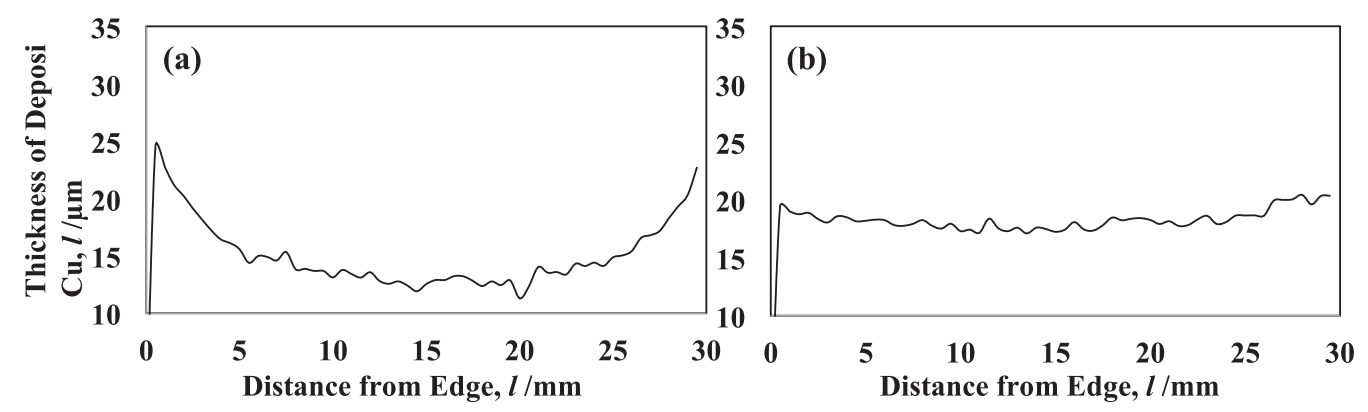

Fig. 6 Thickness profiles of $\mathrm{Cu}$ deposited from solutions without and with the three additives: (a) additive-free and (b) gelatin (1.71 mg.dm $\left.{ }^{-3}\right)$, thiourea $\left(0.023 \mathrm{mmol} \cdot \mathrm{dm}^{-3}\right)$, and $\mathrm{Cl}^{-}\left(1.65 \mathrm{mmol} \cdot \mathrm{dm}^{-3}\right)$.

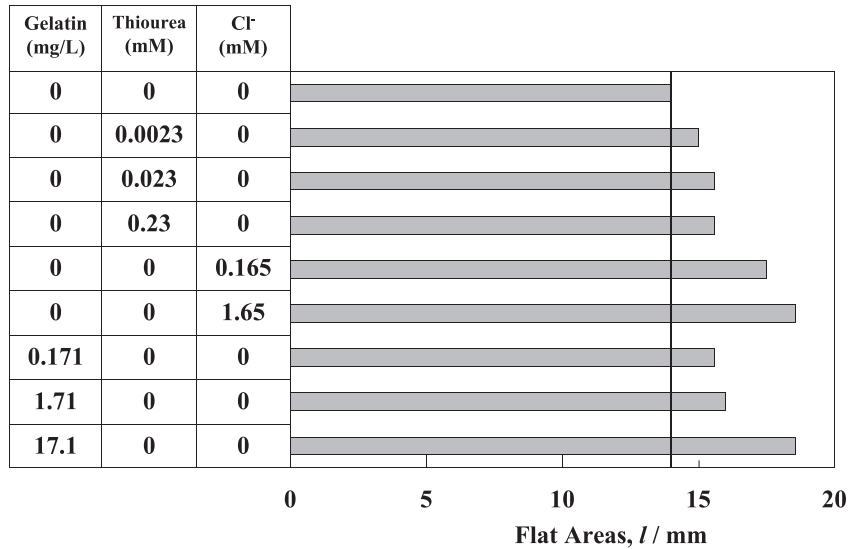

Fig. 7 Throwing powers of $\mathrm{Cu}$ deposited from solutions containing single additives.

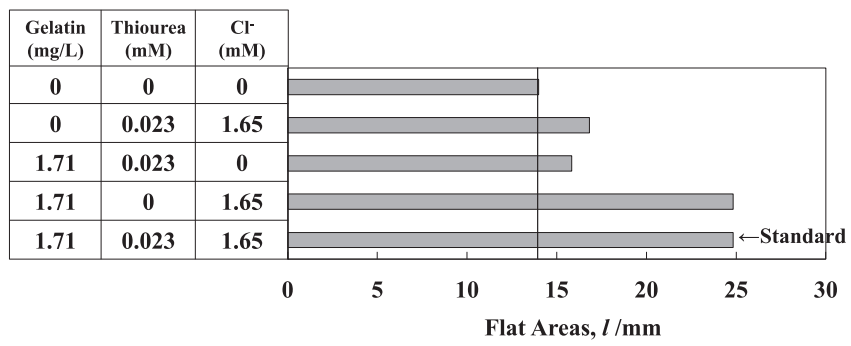

Fig. 8 Throwing powers of $\mathrm{Cu}$ deposited from solutions containing two kinds of additives.

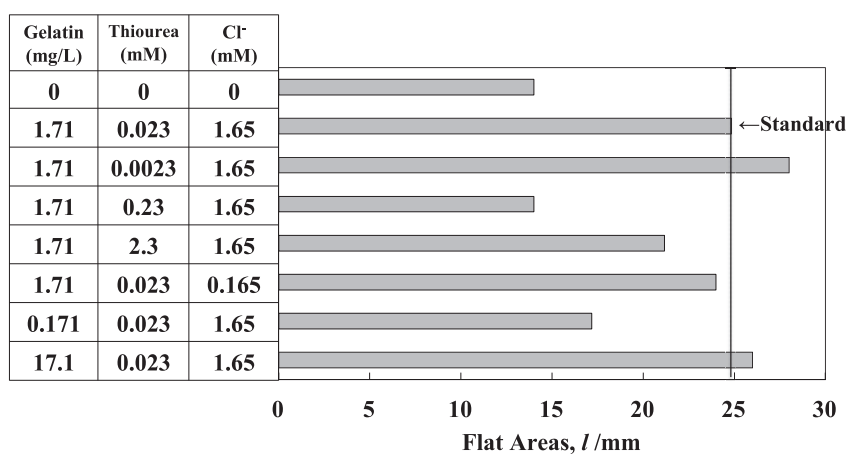

Fig. 9 Throwing powers of $\mathrm{Cu}$ deposited from solutions containing three kinds of additives. the throwing power to worsen. The throwing power of $\mathrm{Cu}$ significantly decreased when the gelatin concentration was decreased to $0.171 \mathrm{mg} \cdot \mathrm{dm}^{-3}$, whereas the throwing power was somewhat improved when the gelatin concentration was increased to $17.1 \mathrm{mg} \cdot \mathrm{dm}^{-3}$.

\subsection{Discussion of the effects of additives based on the polarization curve of $\mathrm{Cu}$ deposition}

To discuss the synergistic effects of additives on the surface roughness and throwing power of deposited $\mathrm{Cu}$, the effects of the additives on the polarization curve of $\mathrm{Cu}$ deposition were investigated. Figure 10 shows the polarization curves for $\mathrm{Cu}$ deposition from solutions containing a single additive at the standard concentration. As can be seen from the cathode potential in the current-density region of 100 to $200 \mathrm{~A} \cdot \mathrm{m}^{-2}$ in the polarization curve magnified around $0.3 \mathrm{~V}$ and $200 \mathrm{~A} \cdot \mathrm{m}^{-2}$ [Fig. 10(b)], all the additives somewhat showed the polarization effect on the $\mathrm{Cu}$ deposition. However, with increasing current density above $200 \mathrm{~A} \cdot \mathrm{m}^{-2}$, thiourea showed a depolarization effect on the $\mathrm{Cu}$ deposition; that is, thiourea promoted $\mathrm{Cu}$ deposition. At $200 \mathrm{~A} \cdot \mathrm{m}^{-2}$, the polarization resistance, which indicates the slope of the polarization curve $(\mathrm{d} E / \mathrm{d} i)$, was lower with the addition of thiourea compared to the additive-free solution.

Figure 11 shows the polarization curves for $\mathrm{Cu}$ deposition from solutions containing various amounts of thiourea as a single additive. As shown in Fig. 11(b), the polarization curve was polarized when the thiourea concentration was increased to 0.23 and $2.3 \mathrm{mmol} \cdot \mathrm{dm}^{-3}$, while it was depolarized above $200 \mathrm{~A} \cdot \mathrm{m}^{-2}$ when the thiourea concentration was decreased to 0.023 and $0.0023 \mathrm{mmol} \cdot \mathrm{dm}^{-3}$. At $200 \mathrm{~A} \cdot \mathrm{m}^{-2}, \mathrm{~d} E /$ $\mathrm{d} i$ was lower at thiourea concentrations of 0.023 and $0.0023 \mathrm{mmol} \cdot \mathrm{dm}^{-3}$ compared to for the additive-free solution. Thus, low concentrations of thiourea promote $\mathrm{Cu}$ deposition.

Figure 12 shows the polarization curves for $\mathrm{Cu}$ deposition from solutions containing various amounts of gelatin as a single additive. As indicated by the polarization curve magnified around $0.3 \mathrm{~V}$ and $200 \mathrm{~A} \cdot \mathrm{m}^{-2}$ [Fig. 12(b)], the polarization was largest at the gelatin concentration of $17.1 \mathrm{mg} \cdot \mathrm{dm}^{-3}$. Little difference in polarization at $200 \mathrm{~A} \cdot \mathrm{m}^{-2}$ was observed between the additions of 0.17 and $1.71 \mathrm{mg} \cdot \mathrm{dm}^{-3}$ gelatin. Upon increasing the gelatin concentration to $17.1 \mathrm{mg} \cdot \mathrm{dm}^{-3}$, the surface roughness of deposited $\mathrm{Cu}$ decreased (Fig. 4), and the throwing power improved (Fig. 7), resulting in the larger polarization. 


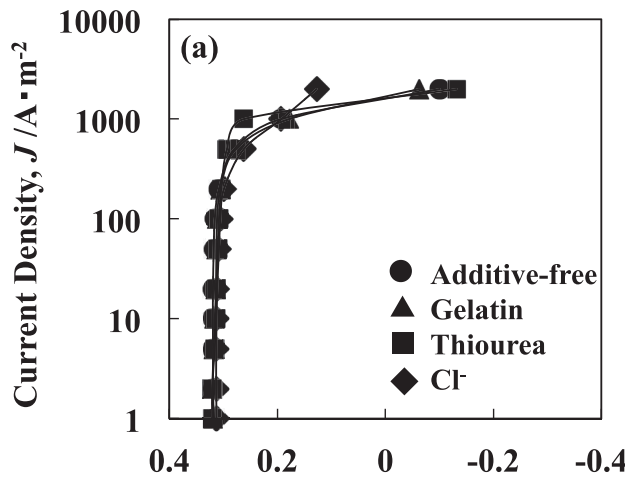

Cathode Potential, $E$ /V vs. NHE

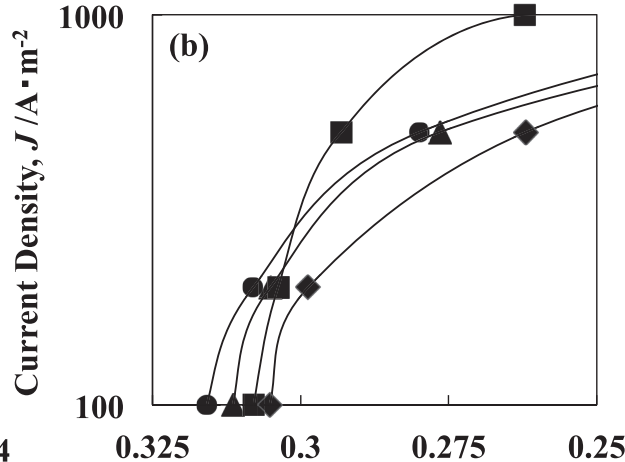

Cathode Potential, $E$ /V vs. NHE

Fig. 10 Normal (a) and magnified (b) polarization curves for $\mathrm{Cu}$ deposition from solutions containing single additives: gelatin (1.71 mg. $\mathrm{dm}^{-3}$ ), thiourea $\left(0.023 \mathrm{mmol} \cdot \mathrm{dm}^{-3}\right)$, and $\mathrm{Cl}^{-}\left(1.65 \mathrm{mmol} \cdot \mathrm{dm}^{-3}\right)$.

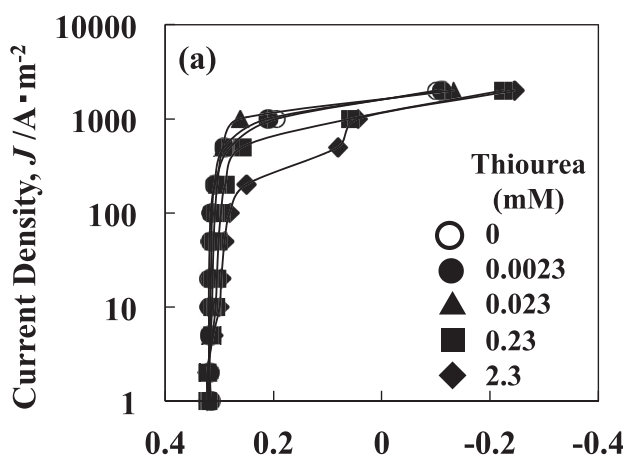

Cathode Potential, $E$ /V vs. NHE

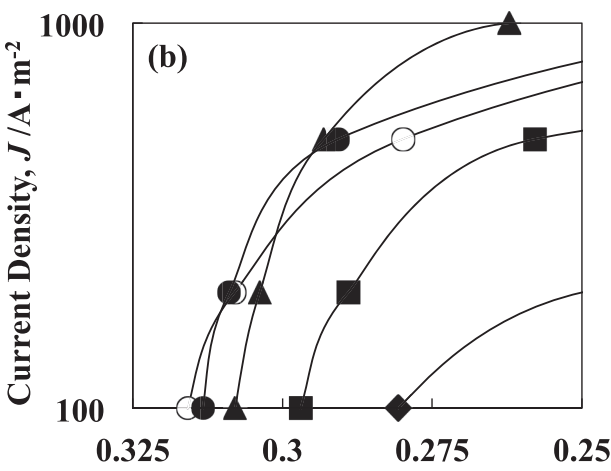

Cathode Potential, $E / V$ vs. NHE

Fig. 11 Normal (a) and magnified (b) polarization curves for $\mathrm{Cu}$ deposition from solutions containing various concentrations of thiourea as a single additive.
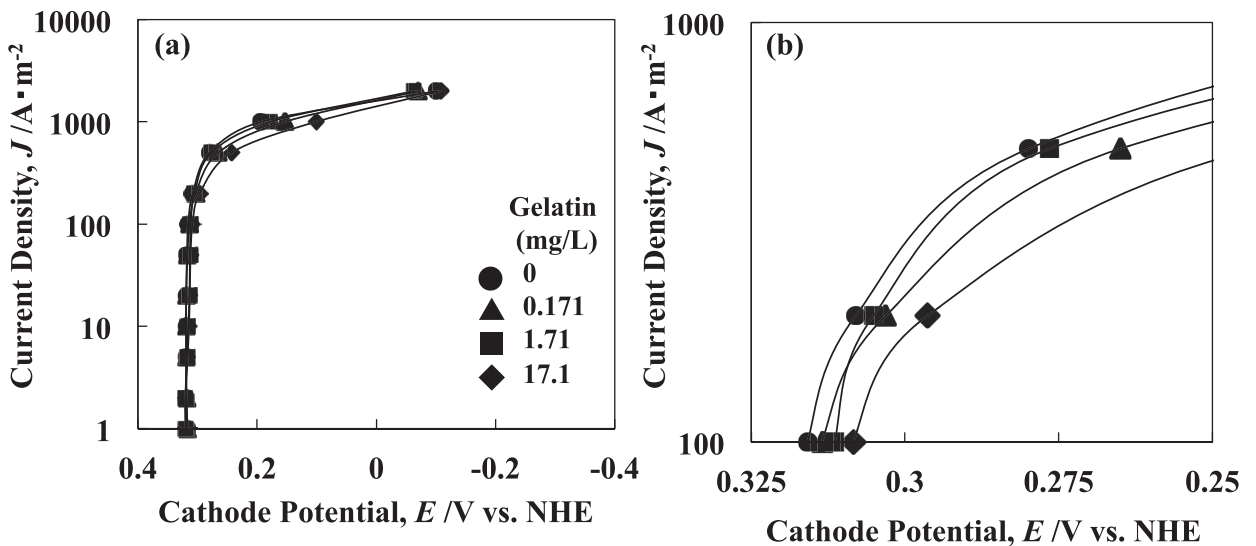

Fig. 12 Normal (a) and magnified (b) polarization curves for $\mathrm{Cu}$ deposition from solutions containing various concentrations of gelatin as a single additive.

Figure 13 shows the polarization curves for $\mathrm{Cu}$ deposition from solutions containing various amounts of chloride ions as a single additive. As shown by the polarization curve magnified around $0.3 \mathrm{~V}$ and $200 \mathrm{~A} \cdot \mathrm{m}^{-2}$ [Fig. 13(b)], $\mathrm{Cu}$ deposition was polarized with the addition of 1.65 and $0.165 \mathrm{mmol} \cdot \mathrm{dm}^{-3}$ chloride ion. It has been reported from the rotating ring disk electrode that $\mathrm{Cu}$ deposition from the solution containing a small amount of chloride ions proceed via adsorbed intermediate $\mathrm{CuCl}_{\mathrm{ad}}{ }^{16)}$ Since the equilibrium po- tential for the reduction of $\mathrm{CuCl}$ to $\mathrm{Cu}$ is less noble than that of the reduction from $\mathrm{Cu}^{2+}$ to $\mathrm{Cu}, \mathrm{Cu}$ deposition seems to be polarized by the addition of chloride ions.

Figure 14 shows the polarization curves for $\mathrm{Cu}$ deposition from solutions containing both gelatin and chloride ions. Although $\mathrm{Cu}$ deposition was hardly polarized by the addition of gelatin only, it was significantly polarized in the presence of both chloride ions and gelatin, indicating the synergistic effect of gelatin and chloride ions on polarization for 

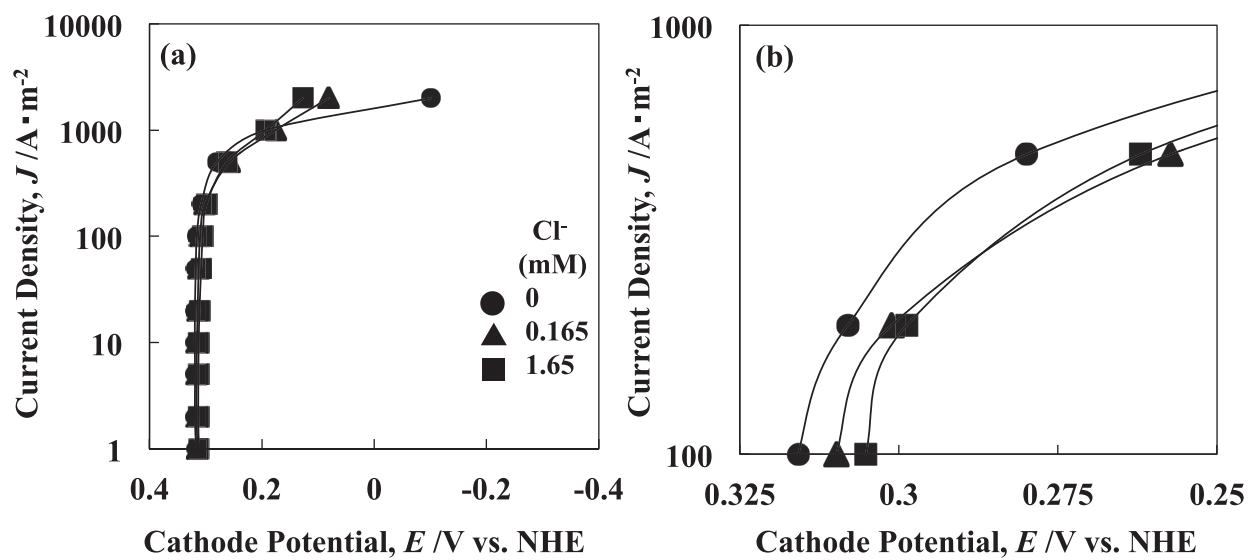

Fig. 13 Normal (a) and magnified (b) polarization curves for $\mathrm{Cu}$ deposition from solutions containing various concentrations of chloride ions as a single additive.
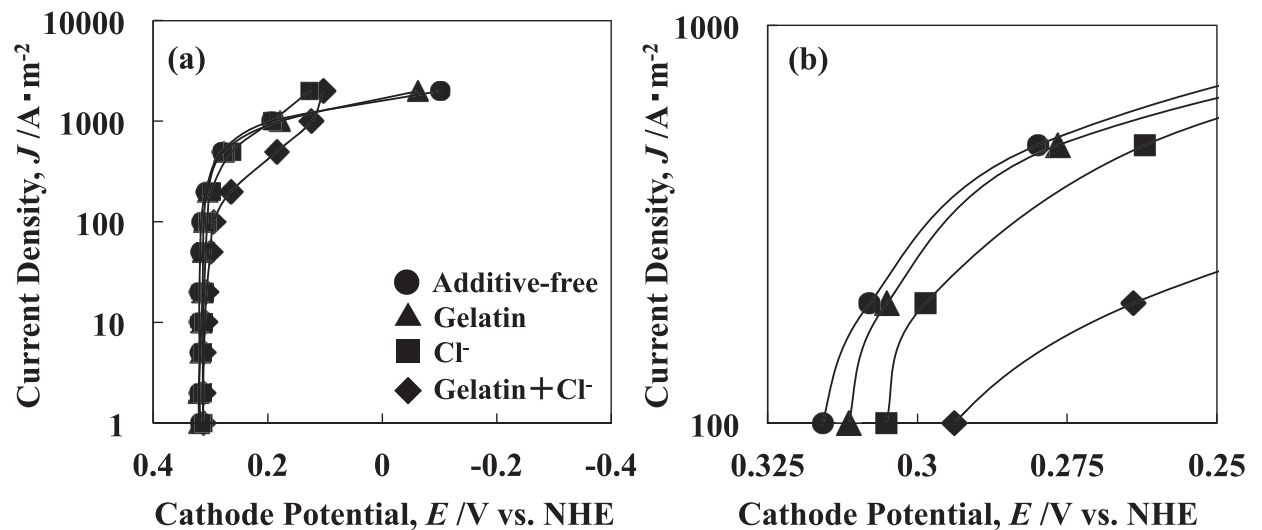

Fig. 14 Normal (a) and magnified (b) polarization curves for $\mathrm{Cu}$ deposition from solutions containing both gelatin (1.71 mg. $\mathrm{dm}^{-3}$ ) and chloride ions $\left(1.65 \mathrm{mmol} \cdot \mathrm{dm}^{-3}\right)$

$\mathrm{Cu}$ deposition. As mentioned above, $\mathrm{Cu}$ deposition from solution containing a small amount of chloride ions proceeds through the intermediate $\mathrm{CuCl}^{16)}$ From the analysis of AC impedance method, the straight-chain polymer additive such as polyethylene glycol is demonstrated to suppress the reduction reaction from the adsorbed intermediate $\mathrm{CuCl}_{\mathrm{ad}}$ to metallic $\mathrm{Cu}^{16)}$ Gelatin is a straight-chain polymer like polyethylene glycol and seems to suppress the reduction of intermediate $\mathrm{CuCl}$ to metallic $\mathrm{Cu}$, which may account for the synergistic effect of gelatin and chloride ions on the polarization of $\mathrm{Cu}$ deposition.

The throwing power of a deposit depends on the current distribution in the electrolytic cell. According to the model calculation of non-uniform current distribution, the distribution of current density significantly depends on the polarization resistance $\mathrm{d} E / \mathrm{d} i$ and becomes uniform with increasing polarization resistance. ${ }^{21,22)}$ In this study, the improvement in the throwing power of deposited $\mathrm{Cu}$ with the addition of both gelatin and chloride ions (Fig. 8) is attributed to an increase in $\mathrm{d} E / \mathrm{d} i$. A small amount of thiourea had a depolarization effect on $\mathrm{Cu}$ deposition (Fig. 11) and is expected to smooth the deposits as a result of the acceleration of $\mathrm{Cu}$ deposition in depressed areas. With the addition of all three additives, the throwing powers of $\mathrm{Cu}$ deposited from solutions containing high concentrations of thiourea $(0.23$ and
$2.3 \mathrm{mmol} \cdot \mathrm{dm}^{-3}$ ) were worse than that of $\mathrm{Cu}$ deposited from the solution containing the standard concentrations of the three additives (Fig. 9). This result is attributed to the elimination of the depolarization effect caused by the increase in thiourea concentration.

\section{Conclusion}

The effects of gelatin, thiourea, and chloride ions on the surface roughness, throwing power, and polarization curves of $\mathrm{Cu}$ deposited from electrorefining solution were investigated. The main conclusions are summarized as follows:

(1) In solutions containing all three additives, the surface roughness of deposited $\mathrm{Cu}$ decreased with increasing thiourea and gelatin concentration and decreasing chloride ion concentration.

(2) The throwing power of deposited $\mathrm{Cu}$ was improved with decreasing thiourea concentration and increasing gelatin concentration in solutions containing all three additives. The throwing power of deposited $\mathrm{Cu}$ was significantly improved in solutions containing both gelatin and chloride ions.

(3) The polarization resistance $\mathrm{d} E / \mathrm{d} i$ for $\mathrm{Cu}$ deposition increased in solutions containing both gelatin and chloride ions, resulting in the improvement of throwing power. 
As small amounts of thiourea have a depolarization effect on $\mathrm{Cu}$ deposition, a smoothing effect is expected owing to the promotion of deposition at recesses.

\section{REFERENCES}

1) C.L. Mantell: Electrochemical Engineering, (McGraw-Hill Book Company, Inc., New York, NY, U.S.A., 1960) pp.142-167, 185-192, 210-224.

2) Hitetsu Kinzoku Seiren, (Nippon Kinzoku Gakkai, Sendai, 1980) p.228, 241.

3) Denki Kagaku Binran, (Denki Kagaku Kyokai, Maruzen, Tokyo,1985) pp.308-327.

4) B. Veilleux, A.M. Lafront and E. Ghali: Can. Metall. Q. 41 (2002) 47-62.

5) K. Shimokawa: Thesis for doctoral degree, (Kyoto University, 2013) pp.19-22.

6) S. Goto, I. Asakura and C. Oshima: J. Mining and Metallurgical Inst. Jpn. 91 (1975) 131-136.

7) S. Goto, O. Ogawa, I. Asakura and C. Oshima: J. Mining and Metallurgical Inst. Jpn. 88 (1972) 99-102.

8) C. Imai and S. Yashima: J. Mining and Metallurgical Inst. Jpn. 73 (1957) 301-305.

9) H. Nakano, S. Oue, T. Ohgai, K. Izumi, T. Akiyama and H. Fukushima: Journal of MMIJ 119 (2003) 663-667.
10) K. Shimokawa, K. Kawaguchi, K. Nishida, K. Murase, H. Sugimura and Y. Awakura: Journal of MMIJ 128 (2012) 155-159.

11) H. Kuboyama, H. Nakano, S. Oue, H. Fukushima and S. Kobayashi: Journal of MMIJ 125 (2009) 62-67.

12) P. Laforest and M. Moats: Proc. Copper 2016,(The Mining and Materials Processing Institute of Japan, 2016) pp.2064-2075.

13) K. Shimokawa, D. Tetsuka, K. Shikada, K. Murase, H. Sugimura and Y. Awakura: Journal of MMIJ 129 (2013) 72-77.

14) K. Shimokawa, M. Narita, I. Sumida, K. Murase, H. Sugimura and Y. Awakura: Journal of MMIJ 126 (2010) 697-700.

15) A. Rodchanarowan and M.L. Free: Mater. Trans. 53 (2012) 1695-1698.

16) H. Nakano, S. Oue, K. Aoya, H. Kuboyama, H. Fukushima and S. Kobayashi: Journal of MMIJ 123 (2007) 165-170.

17) H. Nakano, S. Oue, Y. Tsuyama, H. Fukushima, S. Kobayashi and K. Tomioka: Journal of MMIJ 127 (2011) 662-666.

18) H. Nakano, S. Oue, T. Nishino, H. Kuboyama, H. Fukushima and S. Kobayashi: Journal of MMIJ 128 (2012) 590-595.

19) K. Ando, N. Tsuchida and H. Komi: Shigen-to-Sozai 118 (2002) 86-90.

20) H.M. Abbas and S.T. Najim: Int. J. Curr. Microbiol. Appl. Sci. 6 (2017) 270-284.

21) M. Matlosz, C. Creton, C. Clerc and D. Landol: J. Electrochem. Soc. 134 (1987) 3015-3022.

22) M. Chikuma: J. Surf. Finish. Soc. Jpn. 44 (1993) 583-588. 